\title{
生殖様式を異にするクロゲハナアザミウマの行動学および 化学的識別，ならびに分類学的取り扱い
}

\author{
中尾史郎・養父志乃夫 \\ 和歌山大学システム工学部
}

\begin{abstract}
Ethological and Chemical Discrimination between Thelytokous and Arrhenotokous Thrips nigropilosus Uzel, with Discussion of Taxonomy. Shiro Nakao and Shinobu Yabu (Department of Environmental Systems, Faculty of Systems Engineering, Wakayama University, Sakaedani, Wakayama 640-8510, Japan). Jpn. J. Appl. Entomol. Zool. 42: 77-83 (1998)

Abstract: The mating behavior of Thrips nigropilosus, which consists of arrhenotokous and thelytokous populations, was studied under laboratory conditions. The variation in esterase isozymes of individual adult females from a thelytokous population and seven arrhenotokous populations was analyzed by polyacrylamide gel electrophoresis. Mating occurred between individuals of arrhenotokous populations from different localities. Although males of an arrhenotokous population approached and attempted to copulate with females of a thelytokous population from the same locality, the thelytokous females never accepted the arrhenotokous males. The arrhenotokous populations showed high variability in esterase zymograms, but the thelytokous population had no variation in zymograms. Females reproducing thelytokously and arrhenotokously could be discriminated from each other based on their zymograms. We conclude that arrhenotokous and thelytokous populations should be treated as separate species.
\end{abstract}

Key words: Esterase, arrhenotoky, thelytoky, ethological isolation, Thrips nigropilosus

緒

言

クロゲハナアザミウマ Thrips nigropilosus Uzel は, キ クの害虫として知られている（上住，1988; 池田，1990）. 本種は,イギリスおよびニュージーランドに拈いては雌の みが発見されて扣り, 産雌性単為生殖を行うと考えられて いる (Mound et al., 1976; Walker and Michaux, 1989). これに対し, 日本では本種に雄の出現することが知られて いた（宮崎・工藤，1988; Nakao, 1997）. Nakao（1993） は, 京都産の個体群が産雄性単為生殖を行うことを室内飼 育実験によって確認している. 産雌性単為生殖を行ら雌成 虫は産雄性単為生殖を行 5 雌成虫よりも, 第 9 腹節背板に ある一対の鐘状感覚器間の刻線の発達が弱い傾向がある が，これによって両者を完全に識別することはできず，両 者の識別に利用できる特定の外部形態は見いだされていな い(中尾，未発表).

本種では，雌に翅多型性のあることが知られている (Uzel, 1895; Morison, 1957; Mound et al., 1976; Walker and Michaux, 1989; Nakao, 1993). 近年，わが国におい ても, 稚内市に本種の産雌性単為生殖個体群が生息するこ とが確認された (中尾, 未発表).これを端緒として, 稚 内市で採集した産雌性単為生殖個体群と稚内市から那覇市 までの地域数地点で採集した産雄性単為生殖個体群の翅型
発現性の比較を行った. その結果, 同所的に生息する生殖 様式の異なる個体群間にも, 産雄性単為生殖を行ら異なる 地域個体群間にも翅型発現性の顕著な相違のあることが明 らかになった (中尾ら, 1997; 中尾, 未発表). 同種であ りながら個体群間で翅型発現性に顕著な差異のあること は，相互の遺伝子移入に制限がある可能性を示唆する。し かし, 生殖様式の異なる個体群間の生殖的隔離が完全であ るか否か, また, 生殖様式の異なる個体群間にどの程度の 形質状態の差異があるのかについては不明である.さらに, 産雄性単為生殖を行ら異なる地域個体群間の形質状態の差 異や，相互の遺伝子移入の実態は明らかでない.

産雌性単為生殖を行ら個体群は, 遺伝的に独立したク ローンの集合体であると考学られるため, その分類学的取 り扱いに生物学的種の概念を適用することはでさない.ア ザミウマ類では生殖様式を異にする個体群, 特よび雄産生 能力の異なる個体群が命名法上の同種とされているが (例えば, Mound, 1976; Zawirska, 1976; Kendall and Capinera, 1990)，このように生物学的性質の大きく異な る個体群を同種とすることは, アザミウマ類の分類学の進 展および防除体系の構築の上で大さな障害となることが考 えられる.アブラムシ類はアザミウマ類と同様に, 種内に 生殖様式の異なる個体群が存在する昆虫群であるが, 近 年, 産雌性単為生殖を行らアブラムシの分類学的取り扱い 
に関するガイドラインが提案されている（Blackman and Brown, 1991)。このガイドラインは，アブラムシ類ばか りでなくアザミウマ類の分類の実践に颃いても利用価值の 高いものであり，これによって単為生殖を行うアザミウマ 類の分類学的位置を再検討することの意義は高いと考兄ら れる. このガイドラインに従って, 単為生殖する生物の分 類学的位置を明確にするには, 近縁種, 生殖様式の異なる 同種個体群，そしてクローン系列の形質状態を総合的に判 断し，それぞれの独自性を明確にすることが必要とされる。

そこで, 本研究では, クロゲ八ナアザミウマの異なる地 域個体群間, 抢よび生殖様式の異なる個体群間に生殖的隔 離機構が成立しているか否かを確認して, 個体群間の遺伝 子移入の可能性について検討した. さらに, 産雌性単為生 殖を行ら稚内個体群, 拉よび産雄性単為生殖を行ら稚内か ら那覇までの異なる地域個体群のエステラーゼザイモグラ ムを調査し, 個体群間の遺伝的差異を明らかにした。これ らの結果から, 本種の分類学的取り扱いについて議論した.

本研究の遂行にあたっては, 京都府立大学農学部の高田 肇教授, 吉安裕助教授, 阿部芳久助手より終始貴重なご助 言を賜った. 静岡市の工藤嚴博士, 蚎糸・昆虫農業技術研 究所の宮崎昌久博士, 東京農業大学の岡島秀治博士, Forschungsinstitut Senkenberg の R. zur Strassen 博士には, アザミウマ類の分類学に関するご助言を賜った。 また, 電 気泳動の実施扣よびゲルの写真撮影にあたっては, 京都府 立大学農学部の山本明氏（現在, 北興化学株式会社）と中 村崇氏のご協力を賜った．那霸個体群の採集には沖縄県農 業試験場の宮竹貴久氏のご協力を賜った。 ここに記して, 厚く御礼申し上げる.

材料および方法

\section{1. 供試虫と飼育法}

稚内市, 音威子府村 (北海道中川郡), 網走市, 旭川市, 京都市, 長崎市, 那覇市に扮いて, キク科植物の葉から採 集した雌成虫を創設者として, Nakao（1993）の方法で, キク Chrysanthemum morifolium Ramat. (品種 : 国華創 量) 拉よびカボチャCucurbita maxima Duch. (品種 : 近
成えびす，および栗えびす）の葉片を寄主として継代飼育 した 8 個体群を供試した（Table 1)。これらの個体群は $18^{\circ} \mathrm{C}$, 明期 15 時間-暗期 9 時間条件（以下， $15 \mathrm{~L}-9 \mathrm{D}$ 之略 記）において飼育した．配偶行動の観察扰よびェステラー ゼザイモグラムの検出に供試したすべての個体は,キク（品 種 : 国華創曇) の葉片を寄主として飼育した．稚内市で採 集した雌を創設者とする個体群のうち，産雌性単為生殖を 行らものを稚内 $\mathrm{T}$ 個体群, 産雄性単為生殖を行うものを 稚内 $\mathrm{A}$ 個体群と称する（Table 1).

\section{2. 配偶行動の観察}

配偶行動の観察には, 稚内 $\mathrm{T}$ 個体群, 稚内 $\mathrm{A}$ 個体群特 よび京都個体群の 2 または 3 日齢, および 30 または 31 日 齢の雌成虫, ならびに稚内 $\mathrm{A}$ 個体群および京都個体群の 2 または 3 日齢の雄成虫を供試した。供試個体群の雌雄を 第 2 蛹期に個別にして飼育し, $18^{\circ} \mathrm{C}, 15 \mathrm{~L}-9 \mathrm{D}$ で羽化させ た。さらにこれらを 4 または 5 日扣さに新たな飼育容器 に移し替えながら同条件で個別に飼育した。これら倠雄成 虫を各 1 匹ずつゼラチンカプセル（0号；長径 $22 \mathrm{~mm}$, 短径 $7 \mathrm{~mm}$ ) 飞收容して, $18^{\circ} \mathrm{C}$ 照明下に拈いて配偶行動 を 18 分間観察した。観察開始から雌雄が最初に接触する までの時間，および交尾時間を記録した．また，配偶行動 を雄の行動に基づいて 4 段階に類別し，雄がどの段階まで 容認されるかを調查した. 配偶行動の 4 段階は次のとおり である：(1)第 1 段階; 雄が倠と接触する, (2)第 2 段階; 雄 が倠を触角でたたく，(3)第 3 段階; 雄が雙の背面に乗る， または脚を掛ける，(4)第4段階；交尾する（Fig. 1). 観 察時間内に交尾が観察された場合には，交尾後，雌を新た な飼育容器に個別に移して約 4 日間産卵させた。稚内 A 個体群および京都個体群の配偶行動観察時間内に交尾が観 察されなかった場合には, 観察終了直後より雙雄を新たな 飼育容器に収容して約 24 時間飼育した。 さらにその後, この容器から雄を除き, 倠のみを約 3 日間飼育して産卵さ せた．以上のようにして雌が約 4 日間に産した子世代を, Nakao（1993）の方法で $18^{\circ} \mathrm{C} ， 15 \mathrm{~L}-9 \mathrm{D}$ において羽化する まで飼育し，その性を判別した．子世代に雌が出現した場 合には，親世代虫の交尾が成立していたものと判断した．

Table 1. Population of Thrips nigropilosus used in study

\begin{tabular}{lllcc}
\hline Population & Locality & \multicolumn{1}{c}{ Month and year } & $\begin{array}{c}\text { No. of } \\
\text { founders }\end{array}$ & Mode of reproduction \\
\hline Wakkanai-T & Wakkanai & October 1992 and July 1994 & 3 & Thelytoky \\
\hline Wakkanai-A & Wakkanai & October 1992 and July 1994 & 42 & Arrhenotoky \\
Otoineppu & Otoineppu & July 1994 & 11 & Arrhenotoky \\
Abashiri & Abashiri & October 1992 & 20 & Arrhenotoky \\
Asahikawa & Asahikawa & July 1994 & 20 & Arrhenotoky \\
Kyoto & Kyoto & March 1990, 1991 and May 1993 & 40 & Arrhenotoky \\
Nagasaki & Nagasaki & March and August 1994 & 32 & Arrhenotoky \\
Naha & Naha & September 1994 & 12 & Arrhenotoky \\
\hline
\end{tabular}




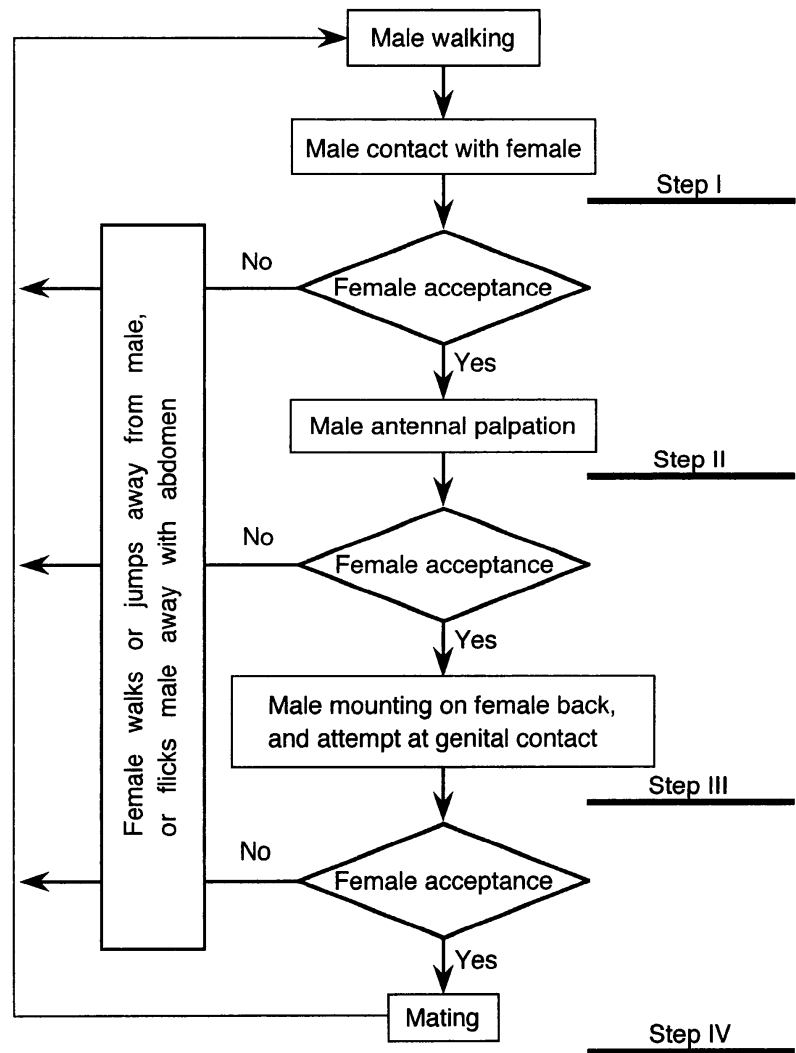

Fig. 1. Diagram of courtship behavior of Thrips nigropilosus.

\section{3. 電気泳動法によるエステラーゼ変異の解析}

全 8 個体群の雌のエステラーゼザイモグラムを, 1-ナフ チルアセテートを基質としたポリアクリルアミド・ゲル 1 次元電気泳動法によって検出した，供試虫は 4 日齢の生き た雌成虫および同日龄時より $-30^{\circ} \mathrm{C} て ゙$ 保存した雌成虫と した。供試雌虫数は, 稚内 $\mathrm{T}$ 個体群 124 匹, 稚内 $\mathrm{A}$ 個体 群 67 匹, 音威子府個体群 9 匹, 網走個体群 24 匹, 旭川個 体群 15 匹，京都個体群 68 匹，長崎個体群 40 匹，および
那覇個体群 12 匹とした。ただし，京都個体群については， 68 匹の雌のらちの一部の親世代括よび子世代虫も同様に 供試した。成虫 1 匹を，40\%ショ糖と $0.5 \%$ Triton X を 4:1 の割合で混合した溶液 $20 \mu 1$ 中でガラス棒でホモジナ イズしたものを酵素液とした。酵素液 $18 \mu \mathrm{l}$ を各ウェルに 注入し，電気泳動を行った。支持体はポリアクリルアミド

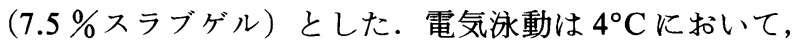
$50 \mathrm{~mA}, 137 \sim 293 \mathrm{~V}$ の条件で 60 分間行った. 泳動終了後, ゲルを $20^{\circ} \mathrm{C} に$ 执いて1ーナフチルアセテートと Fast Blue $\mathrm{BB}$ の混合染色液で約 50 分間染色した。これを水洗，乾 燥した後, 活性泳動帯を調査した。

$$
\text { 結果 }
$$

\section{1. 配偶行動}

稚内 $\mathrm{A}$ 個体群の雌雄の組み合わせでは，88\%(2～ 3 日 路雌）から $100 \%(30 \sim 31$ 日齢雌) の対が，18 分以内に配 偶行動の第 4 段階である交尾に到達した（Table 2). 稚内 A 個体群および京都個体群の組み合わせでは，18 分以内 にこの段階に到達した対は 50〜75\%であった。しかし， これらの組み合わせのいずれにおいても，24 時間以内に は全供試対が交尾した（Table 2). 稚内 $\mathrm{T}$ 個体群と稚内 $\mathrm{A}$ 個体群の組み合わせでは，第 2 段階以降の行動に移った対 は $40 \%(2 \sim 3$ 日齢雌) から $13 \%(30 \sim 31$ 日齢隼)，第 4 段階に到達した対は $0 \%$ であった。また，どの供試対にお いても 24 時間以内に交尾は成立しなかった（Table 2). な抏，実験開始から初めて雄と接触するまでに要した時間 には, 稚内 $\mathrm{T}$ 個体群と稚内 $\mathrm{A}$ 個体群の同日龄の雌間に有 意差は認められなかった（Table 2; Mann-Whitney の $U$ 検定, $p>0.05)$.

2. エステラーゼパターン

本種雌成虫のエステラーゼザイモグラムには移動度の顕 著に異なる 9 群（移動度の遅いものから順に A I ）26本 （移動度の遅いものから順に 1 26）の泳動帯が検出され

Table 2. Courtship and mating success within and between populations of Thrips nigropilosus

\begin{tabular}{|c|c|c|c|c|c|c|c|c|c|}
\hline \multicolumn{3}{|c|}{ Population $^{1)}(\mathrm{d}$ old $)$} & \multirow{2}{*}{$\begin{array}{c}\text { No. of } \\
\text { pairs } \\
\text { observed }\end{array}$} & \multirow{2}{*}{$\begin{array}{c}\text { Mean duration }( \pm \text { S.E. }) \\
\text { before both sexes } \\
\text { contact each other }(s)\end{array}$} & \multicolumn{4}{|c|}{$\begin{array}{l}\left.\text { Category }{ }^{2}\right) \text { of courtship behavior } \\
\text { attained within } 18 \mathrm{~min}(\% \text { of pairs })\end{array}$} & \multirow{2}{*}{$\begin{array}{l}\text { Mating success } \\
\text { within } 24 \mathrm{~h} \\
(\% \text { of pairs })\end{array}$} \\
\hline Female & & ale & & & Step I & Step II & Step III & Step IV & \\
\hline WA $\quad(2-3)$ & WA & $(2-3)$ & 14 & $180 \pm 63$ & 0 & 0 & 0 & 100 & 100 \\
\hline WA $\quad(30-31)$ & WA & $(2-3)$ & 8 & $373 \pm 109$ & 0 & 0 & 12.5 & 87.5 & 100 \\
\hline WA $\quad(2-3)$ & $\mathrm{K}$ & $(2-3)$ & 8 & not examined & 25.0 & 25.0 & 0 & 50.0 & 100 \\
\hline$(2-3)$ & WA & $(2-3)$ & 8 & not examined & 0 & 25.0 & 0 & 75.0 & 100 \\
\hline WT $\quad(2-3)$ & WA & $(2-3)$ & 15 & $272 \pm 56$ & 60.0 & 26.7 & 13.3 & 0 & 0 \\
\hline WT $\quad(30-31)$ & WA & $(2-3)$ & 8 & $252 \pm 73$ & 87.5 & 0 & 12.5 & 0 & 0 \\
\hline
\end{tabular}

1) WA, WT and K mean Wakkanai-A, Wakkanai-T, and Kyoto populations, respectively.

2) See Fig. 1. 
た、A 叔よび B 群はそれぞれ 2 本の泳動帯から構成され たが，これらの移動度の差は軽微で，活性の低い場合には その識別が容易でなかったため, 詳細な解析に不適であっ た。また， E 群は活性域の広い不明瞭な泳動帯 11 を含む が，これは近隣に出現する泳動帯と接するために解析に不 適であった。したがって，エステラーゼザイモグラムの個 体群間変異はこれら 3 群を除く6 群 19 本の泳動带によっ て評価した. 産雌性単為生殖を行ら稚内 $\mathrm{T}$ 個体群の $\mathrm{C}$ 群, $\mathrm{D}$ 群, F 群, G 群, H 群, I 群泳動帯は単型で, C 群 (7), $\mathrm{D}$ 群 (9), F 群 $(13,14), \mathrm{G}$ 群 $(15,16,18,20), \mathrm{H}$ 群 (-), I 群（26）であった（Fig. 2)。このうち，D群 (9)，F 群
(13, 14), I 群（26）は産雄性単為生殖個体群には認めら れず，本個体群に特異的に出現した。これに対し，産雄性 単為生殖を行ら個体群には, 産雌性単為生殖を行ら稚内 T 個体群の䧳とは異なり, H 群に常に泳動帯が出現した. 産雄性単為生殖を行らいずれの個体群に和いても H 群に は 3 本以上の泳動帯が出現したこと, 拈よび京都個体群に 打ける交配実験の結果（Fig. 3) から, 産雄性単為生殖を 行ら各個体群に拈ける $\mathrm{H}$ 群の変異には少なくとも単一遺 伝子座の三つの対立遺伝子が関与するものと思われた．し かし， H 群の泳動带の活性は個体群間で顕著に異なるら え（Fig. 2), 移動度の差は比較的小さいことから (Fig. 4),

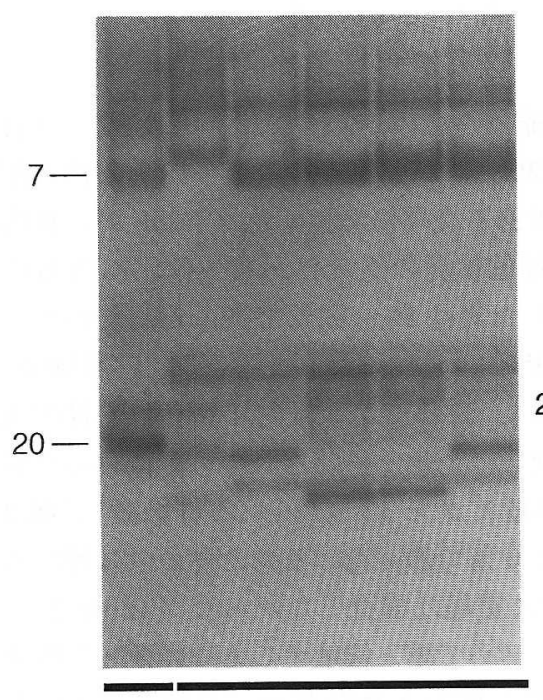

Wakkanai-T Wakkanai-A

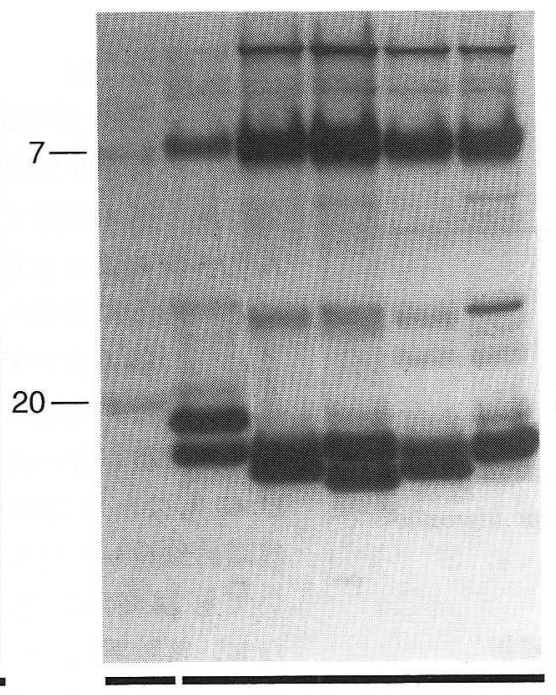

Wakkanai-T Asahikawa

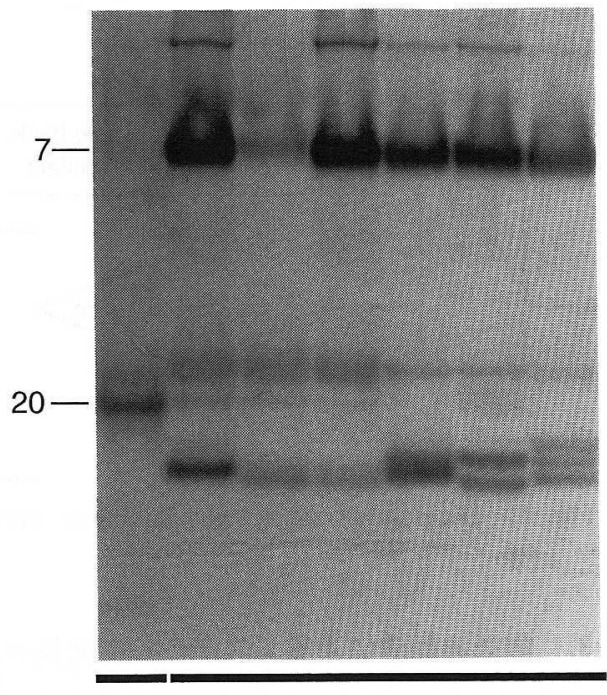

Wakkanai-T Nagasaki

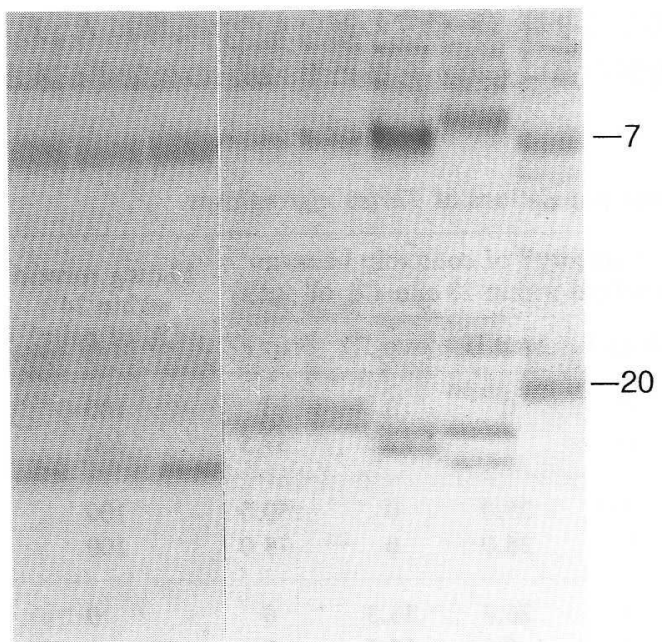

Abashiri
Otoineppu Wakkanai-T
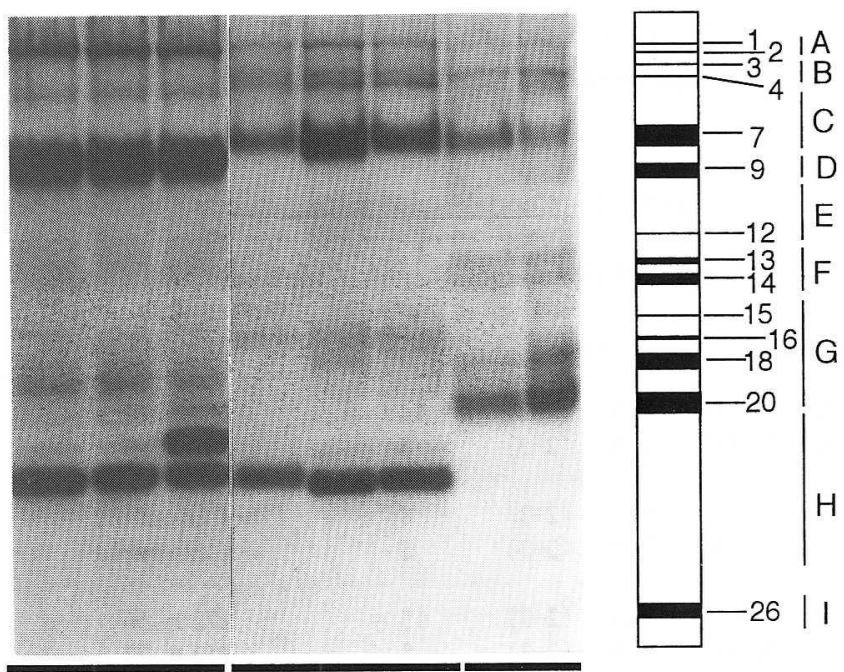

Kyoto

Naha Wakkanai-T

Fig. 2. Esterase zymograms of adult females of eight populations of Thrips nigropilosus. 


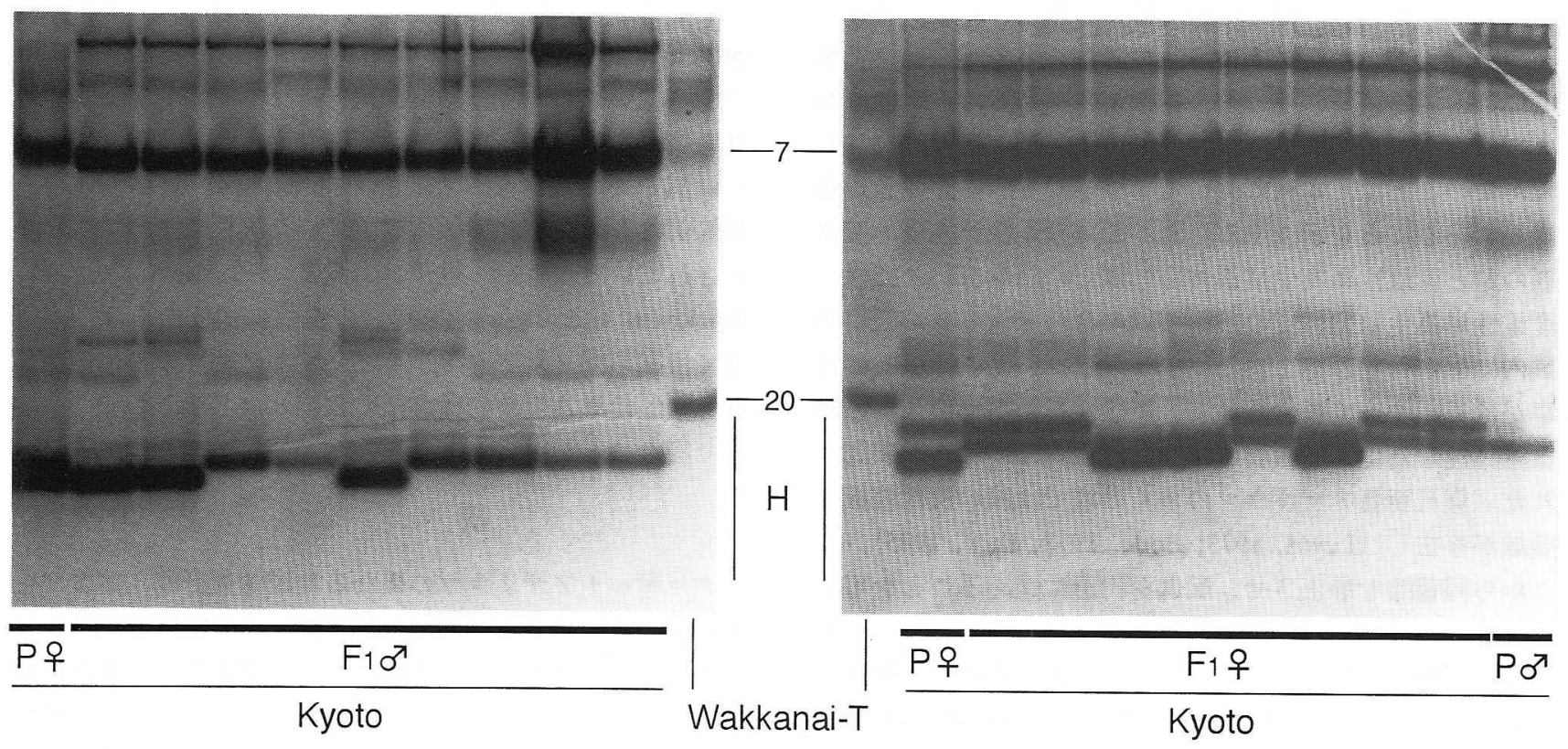

Fig. 3. Esterase zymograms of parents (P) and offspring (F1) of Thrips nigropilosus from Kyoto population.

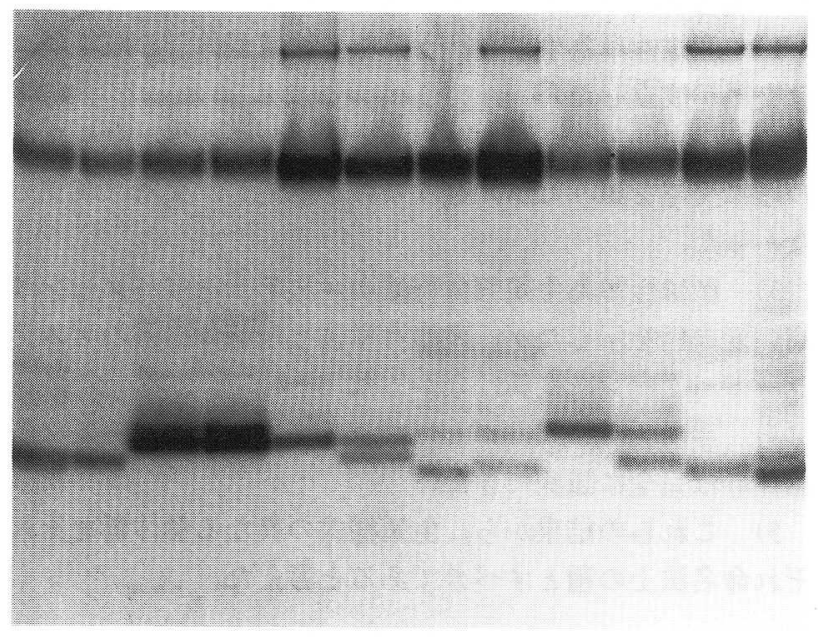

Fig. 4. Intra-population variation of esterase zymograms of adult females of Thrips nigropilosus from Kyoto population.

遺伝子座数や対立遺伝子数の決定には，更なる検討が必要 であった．C群には検出したザイモグラムすべてに1本の 泳動带を認めた。稚内 A 個体群には泳動帯 5, 6, 7 または 8 , 音威子府個体群には 6 または 7 , 網走個体群には 7 また は 8を認めたが, 旭川, 京都, 長崎挆よび那覇個体群には 泳動帯 7 のみを認めた. G 群には泳動帯 $15,16,17,18,19$, 20,21 が発現するが，このうち，15，16，17，18，19 および 21 は全供試個体群で確認することができた。泳動帯 20 は 旭川拉よび那覇個体群を除く個体群に発現した。しかし， この泳動帯を認めた個体は音威子府個体群で 9 匹中 1 匹, そして網走個体群で 24 匹中 2 匹と少なかった。旭川およ
び那覇個体群では標本数がともに 15 匹以下で少なかった ために検出でさなかったのかもしれないなな拉，C拉よび $\mathrm{H}$ 群の泳動帯の活性には個体群間に一定の相違が見られ た。すなわち, 旭川, 京都, 長崎蛒よび那覇個体群の C および $\mathrm{H}$ 群には稚内 $\mathrm{A}$, 音威子府, および網走個体群の それぞれ同群よりも顕著に高い活性の泳動帯が出現した. これらの結果から, 本種は産雌性単為生殖を行ら稚内 $\mathrm{T}$ 個体群と産雄性単為生殖を行う 7 供試個体群の 2 群汇類別 できた。 さらに後者は稚内 $\mathrm{A}$, 音威子府执よび網走個体 群からなる 1 群, ならびに旭川, 京都, 長崎叔よび那覇個 体群からなる 1 群とに類別できることが示唆された。<smiles>[124IH]</smiles>

稚内に和いて同所的に生息しているクロゲハナアザミウ 又産雄性単為生殖個体群々産雌性単為生殖個体群の交配実 験の結果, 雄は両個体群の雌に接近して交尾を試みること が明らかになった。 しかし, 産雄性単為生殖を行ら雌は雄 を受け入れるが，産雌性単為生殖を行ら雌は雄を受け入れ なかった.この結果は, 雌の日齢に関わらず同じであった. このことは, これら両個体群には完全な交尾前の生殖的隔 離機構が存在していることを示唆する。一方, 産雄性単為 生殖を行う稚内個体群之京都個体群の交雑実験により, 異 所的に生息する産雄性単為生殖個体群間には生殖的隔離が 成立していないことが示された。

アザミウマ科の雄では, 同種の雌のみならず別種の雌に も交尾を試みることが知られている（Lewis，1973； Kirk， 1985）。この場合，別種の雌個体は色彩およびサイズが同 種の䧳個体と類似していることから，雄は視覚的に配偶者 
を認識して接近し，配偶行動に移るる考えられる.クロゲ 八ナアザミウマの産雌性単為生殖個体群と産雄性単為生殖 個体群の雌は同様の色彩およびサイズである. 本研究に拉 いては, すべての供試対に括いて, 雄が雌に接近, 接触し た.このことは, 本種においても雄が視覚的に配偶者を認 識していることを示唆する. しかし, 産雄性単為生殖個体 群の雄と産雌性単為生殖個体群の雌々の組み合わせでは, 産雄性単為生殖個体群の雌雄の組み合わせよりも, 観察時 間内に配偶行動の第 2 および第 3 段階にいたる供試対の比 率が低く, すべての供試対で, 産雌性単為生殖個体群の雌 は産雄性単為生殖個体群の雄を受け入れないことが確認さ れた．穿孔亜目アザミウマの多くの種では雄の腹部腹板に 腺域が存在し (Lewis, 1973; Bode, 1978; Kirk, 1985), こ こから同種雌を静止させ, 配偶を円滑に進めることを可能 にするフェロモンが分泌されることが示唆されている (Kirk, 1985). クロゲ八ナアザミウマ雄の腹板にも腺域が 存在する. 本種では, 生殖様式の異なる個体群間に括いて, フェロモンに対する雌の感受性に相違があるため, 交尾前 の生殖的隔離が成立しているのかもしれない.

败小であるため外部形態の観察が容易でない昆虫類やダ 二類では, 形態的類似種特よび同一種の遺伝的変異体の識 別にタンパクの電気泳動像に出現する多型を利用する方法 が広く利用されている.アザミウマに拈いては，外部形態 では識別不可能なハナアザミウマThrips hawaiiensis (Morgan) 雄とビワハナアザミウマThrips coloratus Schmutz 雄との識別, ならびにネギアザミウマの生殖様 式の異なる個体群の識別がエステラーゼザイモグラムの比 較によって可能であることが実証されている（村井, 1990; Murai, 1990). 本種に拈いてる，生殖様式を異にす る個体群をエステラーゼパターンによって完全に識別する ことができた。

単為生殖を行ら生物をどのような分類単位として認識す るのか，またこれらを命名法上どの上らに取り扱らかにつ いては，理論的な概念の不一致ばかりでなく，実用的な問 題からも統一された基準は存在しない.アブラムシ類はア ザミウマ類と同様に単為生殖を行ら系列を多く含む微小昆 虫である。近年, Blackman and Brown (1991) は, 単為 生殖を行らアブラムシ類の分類学的取り扱いに関する指針 を示した。 この中では, 両性生殖を行ら祖先から独立に派 生した, 識別可能な個別の単為生殖系列をそれぞれ種と見 なすこと, そして, 単為生殖を行う祖先を共有せず独立に 派生したクローン系列は同種としないこと, が提唱されて いる. 本研究において, 配偶行動の観察およびェステラー ゼザイモグラムの比較結果から, 両個体群は完全に識別す ることができ, 個体群間に遺伝的交流のないことが強く示 唆された. また, 産雌性単為生殖個体群にはエステラーゼ ザイモグラムに多型が認められなかった.さらに, クロゲ
八ナアザミウマに拈いては，ミトュンドリア DNA の cytochrome oxidase subunit I 遺伝子領域の塩基配列に基 づく系統樹において, 生殖様式の異なる個体群がそれぞれ 高い信頼度で異なるクラスターを形成することが, 本研究 に供試した稚内 $\mathrm{T}$ 個体群, 稚内 $\mathrm{A}$ 個体群, 京都個体群, 長崎個体群衿よび那覇個体群を用いた解析によって明らか にされている (中尾・村路, 未発表).これらのことから, Blackman and Brown（1991）の提唱に従らならば, 本研 究で供試したクロゲハナアザミウマの産雄性単為生殖個体 群と産雌性単為生殖個体群はそれぞれ命名法上の種として 取り扱らことが妥当と考えられる.

摘要

クロゲハナアザミウマの異なる地域個体群間, および生 殖様式の異なる個体群間に行動学的な生殖的隔離機構が存 在しているか否かを室内実験によって確認して, 個体群間 の遺伝子移入の可能性について検討した. さらに, 産雌性 単為生殖を行う稚内個体群, および産雄性単為生殖を行う 異なる 7 地域個体群のエステラーゼザイモグラムを比較 し，個体群間の化学的差異を明らかにした。

1）産雄性単為生殖を行ら異なる地域個体群の雌雄間に は交尾が成立した。

2）産雄性単為生殖個体群の雄は産雌性単為生殖個体群 の雌に交尾を試みたが, 雌はこれを拒絶し, 交尾は成立し なかった。

3）産雄性単為生殖個体群雌のエステラーゼパターンは 高い変異性を示したが, 産雌性単為生殖個体群雌のエステ ラーゼパターンに変異はなかった.

4）エステラーゼパターンによって，生殖様式の異なる 個体群は完全に識別できた。

5）これらの結果から, 生殖様式の異なる個体群をそれ ぞれ命名法上の種とすべきであると考えた。

\section{引用 文 献}

Blackman, R. L. and P. A. Brown (1991) Morphometric variation within and between populations of Rhopalosiphum maidis with a discussion of the taxonomic treatment of permanently parthenogenetic aphids (Homoptera: Aphididae). Entomol. Gener. 16: 97-113.

Bode, W. (1978) Ultrastructure of the sternal glands in Thrips validus Uzel (Thysanoptera, Terebrantia). Zoomorphologie 90: 53-65.

池田二三高（1990） アザミウマ類. 原色菊の病害虫防除（森田 傳 編). 国華園, 大阪, pp. 154-155.

Kendall, D. M. and J. L. Capinera (1990) Geographic and temporal variation in the sex ratio of onion thrips. Southwestern Entomologist 15: 80-88.

Kirk, W. D. J. (1985) Aggregation and mating of thrips in flowers of Calystegia sepium. Ecol. Entomol. 10: 433-440. 
Lewis, T. (1973) Thrips: Their Biology, Ecology and Economic Importance. Academic Press, London. $349 \mathrm{p}$.

宮崎昌久・工藤 箃（1988） 概説. 農作物のアザミウマ（梅谷 献二・工藤 嚴・宮崎昌久 編). 全国農村教育協会, 東京, pp. 33-91.

Morison, G. D. (1957) A review of British grasshouse Thysanoptera. Trans. R. Entomol. Soc. Lond. 109: 467-534.

Mound, L. A. (1976) The identity of the greenhouse thrips Heliothrips haemorrhoidalis (Bouche) (Thysanoptera) and the taxonomic significance of spanandric males. Bull. Entomol. Res. 66: 179-180.

Mound, L. A., G. D. Morison, B. R. Pitkin and J. M. Palmer (1976) Thysanoptera. In Handbooks for the Identification of British Insects. Vol. 1, Part 11 (A. Watson ed.). Royal Entomological Society of London, London. $79 \mathrm{p}$.

村井 保（1990） アザミウマ類のアイソザイムによる識別法. 植物防疫 44: 229-232.

Murai, T. (1990) Parthenogenetic reproduction in Thrips tabaci and Frankliniella intonsa (Insecta: Thysanoptera). In $A d$ vances in Invertebrate Reproduction 5 (Proceedings of the 5th International Congress of Invertebrate Reproduction) (M. Hoshi and O. Yamashita eds.). Elsevier Science, Amsterdam, pp. 357-362.
Nakao, S. (1993) Effects of temperature and photoperiod on wing form determination and reproduction of Thrips nigropilosus Uzel (Thysanoptera: Thripidae). Appl. Entomol. Zool. 28: 463-472.

Nakao, S. (1997) Overwintering and seasonal changes in wing form composition of Thrips nigropilosus Uzel (Thysanoptera; Thripidae) in Kyoto, Japan. Appl. Entomol. Zool. 32: 49-56. 中尾史郎 - 養父志乃夫 - 中島敦司（1997）遠隔地からの緑化植 物の移植が昆虫の地域個体群へ及ぼす影響. 環境システム研 究 25: 665-669.

上住 泰 (1988) クロゲ八ナアザミウマ. 農作物のアザミウマ (梅谷献二.工藤 嚴・宮崎昌久 編). 全国農村教育協会, 東京, pp. 313-314.

Uzel, H. (1895) Monographie der Ordnung Thysanoptera. Koniggratz, Bhomen. $472 \mathrm{p}$.

Walker, A. K. and B. Michaux (1989) The chrysanthemum thrips, Thrips nigropilosus Uzel (Terebrantia: Thysanoptera), on Scotch thistle, Cirsium vulgare (Savi) Ten. (Compositae: Cynareae) in New Zealand. N. Z. Entomol. 12: 17-19.

Zawirska, I. (1976) Untersuchungen uber zwei biologische Typen von Thrips tabaci Lind. (Thysanoptera, Thripidae) in der VR Polen. Arch. Phytopathol. Pflanzenschutz 12: 411-422. 